\title{
Role of aquatic insects in the enhancement of biodiversity of a freshwater reservoir, Ramala, Chandrapur, Maharashtra
}

\author{
Kulkarni R. R. and Zade S. B. 网
}

Received: 31.07.2020

Revised: 09.08.2020

Accepted: 03.10.2020

\begin{abstract}
Aquatic biodiversity has enormous economic and aesthetic value and is largely responsible for maintaining and supporting overall aquatic environmental health. Aquatic organisms also rely upon the great diversity of aquatic habitats and resources for food and materials and breeding ground. The aquatic biodiversity gets affected by several factors such as industrial pollution or anthropogenic activities. Present investigation is an attempt to document abundance and diversity of aquatic insects of Ramala reservoir in Chandrapur city of Maharashtra. It has been estimated that total 16 species of insects belonging to 14 families and 4 orders inhabit in and around this reservoir. The study was carried out from June 2017 to April 2018, including the three seasons. Season wise fluctuations were clearly observed in the population of insects which were noticed.
\end{abstract}

Key Words: aquatic insects, anthropogenic activities, biodiversity, industrial pollution, reservoir

\section{Introduction}

Freshwater bodies are very essential for the existence of dynamic ecosystem. The water quality acts as a limiting factor for biotic components in an aquatic ecosystem. Reservoirs play an important role in ecology and maintain ecological balance of flora and fauna. The water quality assessment generally includes physico-chemical parameters and biological analysis. Biological monitoring is a mean of assessing the water quality using living organisms as a sensor. The most commonly used methods for biological assessment depends on kinds, number and abundance of inhabiting species. Reservoirs are artificial water bodies whose dynamics and structures present a pattern of organization midway between those of rivers and lakes. The ecological processes in these ecosystems are much more complex and variable than those found in natural lakes (Agostinho and Gomes, 1997). Insects are dominant component of most of the ecosystem. They play key role in pollination and natural pest control. Insect biodiversity form a vital component of a variety of ecosystem functioning, including aquatic ecosystem. Aquatic insects form an important link in many food chains. They feed upon small invertebrates, small fishes or Author's Address

${ }^{1}$ Department of Zoology, Sardar Patel College, Chandrapur.

${ }^{2}$ Deptt of Zoology' RTM Nagpur University Campus, Nagpur.

E-mail : kulkarnirajlaxmi@gmail.com their fingerlings, aquatic plants, algae, detritus as well as decaying matter. On the other hand, insects themselves become food for birds, fishes, amphibians and reptiles. Aquatic insects are connecting link between the aquatic and terrestrial ecosystem as they contribute to energy and nutrient processing through food chains and also purifying water. Aquatic insects have recreational value as they enhance the beauty of lake, pond or any freshwater body. Aquatic insects are also important bio-indicators of water pollution and overall water quality (Sivaramkrishan et al., 1998). Some aquatic insects are very much useful for the development of fishes as well as macrophytes, control of mosquito's larvae. There is a great deal of diversity represented by aquatic insects. Despite of diversity and abundance of aquatic insects they are often inconspicuous and therefore many times get neglected. Aquatic insects are integrated part of aquatic and terrestrial food chain. These feed on a variety of food types including leaves of aquatic plants, wood, algae, other invertebrates and even some vertebrates such as small fishes or tadpoles. Aquatic insects spend some portion of their life cycle in the water. They have become adapted to aquatic life because of the special structures they have. Several orders of class Insecta such as Odonata, Hemiptera, Coleoptera, Diptera lead their 
life successfully in and around water. Aquatic insects have prominent role in the biodiversity of any lake or reservoir. They also serve as a good indicator of water pollution and considered as biomonitor of aquatic ecosystem. The present study deals with the abundance and diversity of aquatic insects in and around the Ramala reservoir of Chandrapur city during June 2017 to April 2018, including all the three seasons - monsoon, winter and summer.

\section{Material and Methods}

\section{Description of the study area}

Ramala reservoir selected for the study is a perennial rain-fed water body constructed in Chandrapur city by Gond Raja in fifteenth century along the north-east side of city wall. Morphometrically it is situated at $79^{\circ} 18^{\prime} 15^{\prime \prime}$ east longitude and $19^{\circ} 18^{\prime} 15^{\prime \prime}$ North latitude. Water of this reservoir is used for domestic purposes and fish production. It harbours a wide variety of plant and animal species and plays an important role in conservation of nature. It is a recreational site and attracts the citizen for the requirement of fresh air, mental piece and joy. Three sampling stations were selected for studying the biodiversity of insects. Collection and study was carried for a year from June 2017 to April 2018. Early morning hours and late noon hours were chosen for the collection since insects cling to small roots and leaves of aquatic macrophyte such as Hydrilla, Vallisneria, Chara, Eichhornea during these hours and minimum disturbance of anthropogenic activities were found at noon. Aquatic insects in open air were collected with hand net and brought to laboratory for further observation and classification. Insect clinging on vegetation were handpicked and collected. Out of three sampling sites, one is dense with floating and submerged vegetation where maximum numbers of insects were found. The other two having sparse vegetation and bathing, washing area have comparatively less variety of fauna and therefore aquatic insects too. Identification of insects was done using standard literatures and keys (Edmondson, 1959; Tonapi, 1959; Gulati, 2012).

\section{Results and Discussion}

The biodiversity and population dynamics of aquatic insects of Ramala freshwater reservoir was studied for a year, from June 2017 to April 2018. The list of species collected is given in the table 1 . Total 16 species of aquatic insect belonging 14 families and four orders were found in the study. It was also observed that abundance and diversity if insects was governed by many biotic and abiotic factors. Seasonal fluctuations were remarkably observed in population of insects during the study period. Four major orders of aquatic insects were found viz. Diptera, Coleoptera, Odonata and Hemiptera.

Two peaks of population density were observed during the year, the first one in summer season and the second one in winter. Temperature is the most important factor which affects the seasonal cycle and abundance of insects in aquatic ecosystem. Population density of biotic community in aquatic ecosystem is greatly affected by several environmental factors. Temperature is one of the most important physical factors which affect the most. The peak of insect population in summer must have correlation with the temperature which in turn is related to availability of food. Similar seasonal population dynamics regarding aquatic insects was observed by Khanna et al. (2001). It was observed that most of the insects were found on the roots and leaves of aquatic plants.

Two species from order Diptera were found which includes Chironomous larvae (midge larvae) and larvae the three species of mosquitos i.e. Culex, Ades and Anopheles. Chironomid always found in the entire aquatic habitat. These are important food source for insects and fishes. The most important feature of dipteran is their ecological diversity. Chironomid are water quality indicators which can tolerate moderate pollution.

Three species from three different families of two suborder Zygoptera and Anisoptera were found from Odonata. This order majorly includes dragon flies and damsel flies Odonata species flourished when macrophytic growth was luxuriant during summer and winter. Hynes (1974) and Perry (1981) have also reported that Odonata species are distributed in variety of habitat with rich growth of macrophyte. The dragon fly and damsel fly larvae were found to be attached to roots of macrophytes.

There are more than 500 species of Odonata occurring in India (Prasad and Varshney, 1995). Mishra (2007) studied the Odonata of Madhya Pradesh and reported total 70 species belonging to 
40 genera and 09 families distributed in different aquatic. All may be found swimming or clinging to localities. Hemiptera is an order of true bugs. underwater vegetation. All are strong fliers and Hemipterans undergo incomplete and gradual attracted towards the light at night.

metamorphosis. Both adult and larval stages are

Table 1. Classification and characteristics of aquatic insects of Ramala reservoir

\begin{tabular}{|c|c|c|c|c|}
\hline SN & Family & Scientific name & Common name & Feeding habits \\
\hline \multicolumn{5}{|c|}{ Order- Diptera } \\
\hline 1 & Chironomidae & Chironomous sps. & Midge larva & $\begin{array}{l}\text { Detritus \& algae. Water quality } \\
\text { indicator. }\end{array}$ \\
\hline 2 & Culicidae & $\begin{array}{l}\text { Culex sps. } \\
\text { Aedes sps. } \\
\text { Anopheles sps. }\end{array}$ & Mosquito larva & \\
\hline \multicolumn{5}{|c|}{ Order- Odonata } \\
\hline 3 & Gomphidae & Onychogomphous & Dragon fly & Predator \\
\hline 4 & Libelludae & Libellula & Skimmers & Predator \\
\hline 5 & Lestidae & Lestes & Demsel fly & Predator \\
\hline \multicolumn{5}{|c|}{ Order-Hemiptera (True bugs) } \\
\hline 6 & Belostomidae & Belostoma fluminea & Giant water bugs & $\begin{array}{l}\text { Predator, feed on aquatic } \\
\text { crustaceans, small fishes. }\end{array}$ \\
\hline 7 & Corixidae & Sigara sps. & Water boatman & Feed on small aquatic insects \\
\hline 8 & Gerridae & Aquarius remigis & Water striders & $\begin{array}{l}\text { Predators, feed on mosquito } \\
\text { larvae, aquatic insect }\end{array}$ \\
\hline 9 & $\begin{array}{l}\text { Hydrometrida } \\
\text { e }\end{array}$ & Hydrometra martini & Water measurers & $\begin{array}{l}\text { Predators, feed on mosquito } \\
\text { larvae, small aquatic insect }\end{array}$ \\
\hline 10 & Veliidae & Microvelia sps. & Small water striders & Predators, feed on small insects \\
\hline 11 & $\begin{array}{l}\text { Nepidae } \\
\text { Sub family: } \\
\text { Ranatrinae }\end{array}$ & Ranatra brevicollis & Water scorpions & Predators, feed on aquatic insects \\
\hline 12 & $\begin{array}{l}\text { Nepidae } \\
\text { Sub family: } \\
\text { Nepinae }\end{array}$ & Nepa cinera & Water scorpions & Predators, feed on aquatic insects \\
\hline 13 & Notonectidae & Notonecta sps. & Back swimmers & $\begin{array}{l}\begin{array}{l}\text { Predators, feed on aquatic } \\
\text { crustaceans, small fishes }\end{array} \\
\end{array}$ \\
\hline 14 & Pleidae & Neoplea striola & Pigmy Backswimmers & Predators, feed on water fleas \\
\hline \multicolumn{5}{|c|}{ Order-Coleoptera } \\
\hline 15 & Dytiscidae & Cybister sps. & Diving beetle & Predators, feed on tadpole \\
\hline 16 & Dytiscidae & Hydraticus & Diving beetle & Predators, feed on tadpole \\
\hline
\end{tabular}

The ecology of aquatic Hemiptera is much better known and they are limnologically more significant than beetles. They are economically important also as they feed upon mosquito larvae, tadpole, other insects and worms. Some of the bugs are scavengers that help to maintain, some extend the healthy nature of freshwater bodies. Total 9 different species of aquatic bugs belonging to 8 families were found during this study. Thus maximum numbers of species were from order Hemiptera. According to abundance and diversity, Hemiptera stood first in all orders. All the species from this order with their feeding habits are shown in table 1. Almost all of them are predators. Some of them even feed on small fishes and tadpoles. Aquatic Hemipterans are, therefore, economically important because of their feeding habits. These are useful to control mosquito population on one hand but also cause threat to pisciculture. Most hemipteran are lentic forms. They are air breathers and more tolerant to environmental extremes than any other insect group. i.e. order of beetles is largest order of insects but most of them live on land. Most of the water beetles are more common is 


\section{Kulkarni and Zade}

standing or slow moving water. The study revealed only two species of aquatic beetles from the same family. Dytiscidae which are Cybister and Hydraticus, both are commonly called as diving beetle.

\section{Conclusion}

Water beetles feed on algae and small particles of detritus. Some of them are sensitive to water pollution whereas some are tolerant. One of the most attractive features of aquatic insect is their ability to various types of aquatic environment and diverse pattern of distribution in habitat. Because of their ability to indicate the water quality status insects are also considered as bioindicator or biomonitor. Insect population and diversity is related aquatic environment which includes several biotic and abiotic factors. Presence of four major orders of aquatic insects with their 16 representative species indicates moderate environmental condition of Ramala reservoir.

\section{References}

Agostinho, A. A., Ferretti, C. M. L., Gomes, L. C., Hahn, N. S., Suzuki, H. I., Fugi, R. and Abujanra, F. 1997. Ictiofauna de dois reservatórios do rio Iguaçu em diferentes fases de colonização: Segredo e Foz do Areia. In AGOSTINHO, A. A. and GOMES, L. C. (Eds.). Reservatório de Segredo: bases ecológicas para o manejo. Maringá: EDUEM. p. 275-292.
Edmondson, W. T. 1959. Fresh water Biology, Ward and Wipple (Ed), $2^{\text {nd }}$ edition, John Wiley and Sons, Inc, New York.

Gulati, P. 2012. Hand book of Aquatic Insects, Bio-green books publication, New Delhi-2012.

Hynes, H. R. N. 1974. The biology of polluted water. Toronto India. 25 b: 321-332.

Khanna, D. R., Chugh, T. and Sarkar, P. 2001. Fluctuations in the population density of Macro - invertebrates of river Ganga at Pashulok Barrage Rishikesh (Uttaranchal, India). Environment Conservation Jourbnal, 2(1): 37- 39.

Mishra, S. K. 2007. Insecta: Odonata; pp. 245-272, in: The Director (ed.). Fauna of Madhya Pradesh (Including Chhattisgarh). State Fauna Series, 15(1). Kolkata: Zoological Survey of India.

Prasad. M. and Vaeshney, R. K. 1995. A checklist of Odonata of India. Oriental Ins. 29: 385-428.

Perry, T. E. 1981. Dragon flies and damsel flies (Odonata) of the ground river system, North eastern Ohio, 1974-1978.

Sivaramkrishnan, K. G., Madhyasta, N. A. and Subramanian, K. A. 1998. Field guide to aquatic macrovertebrates. Life scope. Centre for Ecological sciences, Indian Institute of Sciences, Banglore.

Tonapi, G. T. 1959. Studies on the aquatic insect fauna of Poona (aquatic Hemiptera). Proceedings of the National Academy of Sciences, India, 25: 321-332. 